ser generalizados dado que incluíram no estudo apenas cultivares de trigo de inverno alemães e que estes cresceram num único local na Alemanha.

Ana Paula Esteves

aesteves@quimica.uminho.pt

\section{Fontes}

Does Modern Wheat Contain More Gluten?, chemistryviews.org/details/ news/11259175/Does Modern Wheat Contain More Gluten (acedido em 03/09/2020)

D. Pronin, A. Börner, H. Weber, K. A. Scherf, J. Agric. Food Chem. 2020, 68, 1324713256. DOI: 10.1021/acs.jafc.Oc02815.

\title{
Gorduras nos Alimentos - Influência no Sabor do Vinho
}

0 vinho é consumido, muitas vezes, à refeição. No entanto, embora seja bem conhecido de qualquer provador ou escanção que o sabor do vinho se altera na presença de alimentos, a influência dos lípidos da dieta na adstringência e amargor do vinho, causados pelos taninos da uva, não está bem estabelecida do ponto de vista molecular. Os taninos são compostos polifenólicos responsáveis pelo amargor (sabor resultante da interação entre taninos e recetores de sabor localizados na cavidade oral) e adstringência (sensação percetível atribuída principalmente à interação entre taninos e proteínas da saliva) de vinhos tintos. Certos alimentos reduzem essas sensações, melhorando o sabor do vinho. No entanto, não se sabe exatamente a razão por que isso acontece. Alguns estudos indicam que os taninos interagem com os lípidos a nível molecular. Nos alimentos, os lípidos são encontrados como glóbulos de gordura dispersos em líquidos ou sólidos.

Julie Géan (Universidade de Bordéus, Pessac, França) e colegas investigaram o modo como os taninos influenciam o tamanho e a estabilidade das gotículas de lípidos numa emulsão. Com a participação de voluntários, avaliaram também como o consumo prévio de óleos vegetais afeta o sabor dos taninos. Os investigadores prepararam uma emulsão de óleo em água usando azeite, água e um fosfolípido (emulsificante). De seguida, adicionaram catequina (um tanino de uva) e estudaram os lípidos na emulsão usando microscopia ótica, microscopia eletrónica e espectroscopia de ressonância magnética nuclear (RMN). As distribuições de tamanho das gotículas foram medidas usando dispersão de luz estática. A equipa de investigação descobriu que o tanino se inseriu na camada de emulsificante que circundava as gotículas de óleo, originando a formação de gotículas maiores. Nos testes de sabor, os voluntários indicaram que o consumo de uma colherada de óleo de colza, de sementes de uva ou de azeite antes de provar uma solução de tanino, reduziu a adstringência dos compostos. 0 azeite teve o maior efeito, fazendo com que os taninos fossem percecionados como frutados em vez de adstringentes. Combinando os resultados biofísicos e sensoriais, estes investigadores concluíram que os taninos podem interagir com as gotículas de óleo na boca, ficando menos disponíveis para se ligarem às proteínas da saliva e causar adstringência.

\section{$>$}

\section{Ana Paula Esteves}

aesteves@quimica.uminho.pt

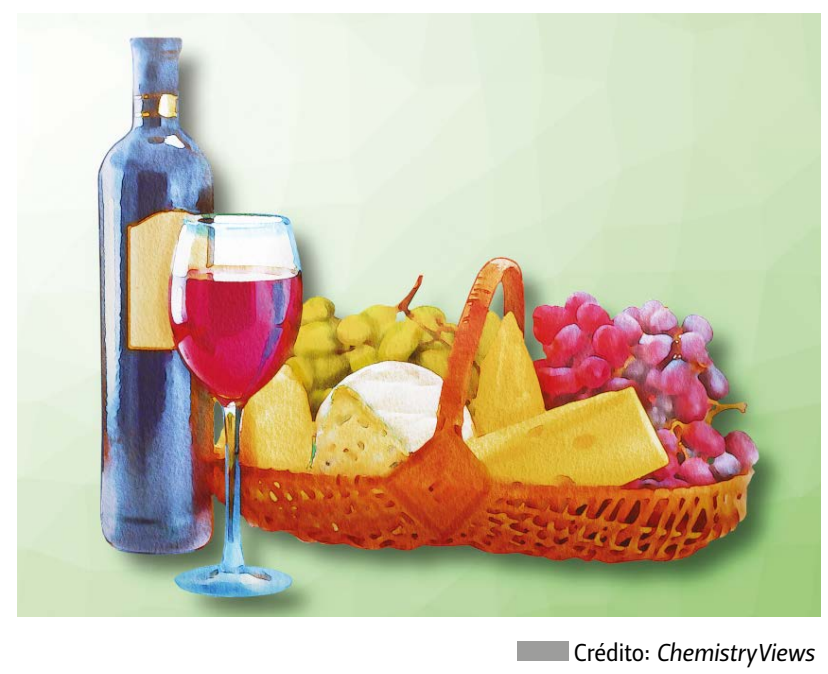

\section{Fontes}

How Fats in Food Influence the Taste of Wine, chemistryviews.org/details/ news/11292901/How_Fats_in_Food_Influence_the_Taste_of_Wine.html (acedido em 16/03/2021).

A. Saad, J. Bousquet, N. F.-Castro, A. Loquet, J. Géan, J. Agric. Food Chem. 2021 69, 3165-3174. DOI: 10.1021/acs.jafc.0c06589. 